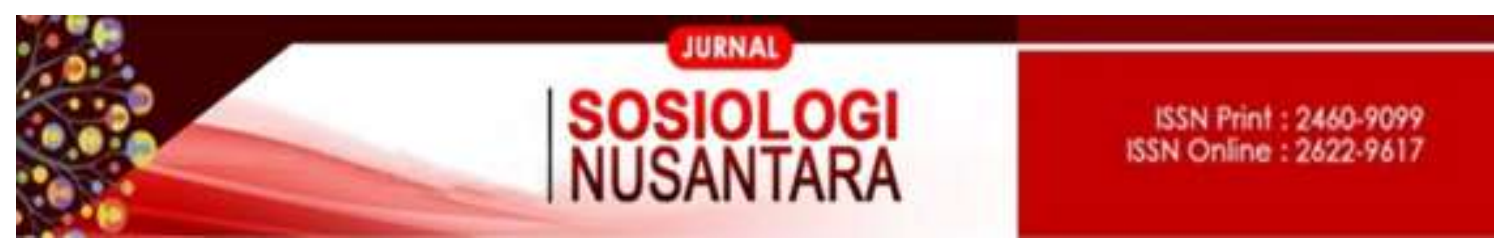

https://ejournal.unib.ac.id/index.php/jsn

DOI://doi.org/10.33369/jsn.5.2.91-112

\title{
KEMISKINAN STRUKTURAL KOMUNITAS NELAYAN DI KELURAHAN SUMBER JAYA, KECAMATAN KAMPUNG MELAYU, KOTA BENGKULU
}

\section{STRUCTURAL POVERTY OF THE FISHERMAN COMMUNITY IN SUMBER JAYA MUNICIPAL, KAMPUNG MELAYU DISTRICT, BENGKULU CITY}

\author{
Eine Yamitha Pinem1, Septri Widiono², Irnad ${ }^{3}$ \\ septriwidiono@unib.ac.id \\ ${ }^{123}$ Fakultas Pertanian, Universitas Bengkulu
}

\begin{abstract}
Abstrak
Kemiskinan adalah kondisi seseorang yang secara ekonomi tidak mampu memenuhi kebutuhannya sesuai dengan standar hidup di suatu daerah. Beberapa nelayan yang tinggal di Kelurahan Sumber Jaya tidak memiliki aset seperti tanah dan perumahan, sehingga mereka memilih untuk menyewa rumah. Penelitian ini bertujuan untuk menguraikan karakteristik kemiskinan dan menganalisis faktor struktural yang membentuk kemiskinan yang terjadi pada masyarakat tersebut. Penelitian ini dilakukan dengan metode kualitatif dengan menerapkan wawancara mendalam kepada beberapa informan kunci, observasi lapangan, dan studi dokumen. Penelitian menemukan bahwa karakteristik kemiskinan masyarakat nelayan dapat dilihat dari kondisi daerah kumuh, akses ke layanan kesehatan yang rendah, tingkat pendidikan yang rendah, dan kondisi ekonomi rumah tangga yang buruk yaitu pendapatan yang tidak pasti, aset produktif yang lebih rendah, dan secara ekonomi tergantung pada juragan. Faktor struktural yang mempengaruhi kemiskinan berasal dari pola hubungan produksi, pola hubungan sosial, kebijakan pemerintah, dan kategori lainnya.
\end{abstract}

Kata Kunci: kemiskinan struktural, komunitas nelayan, Bengkulu

\begin{abstract}
Poverty is the condition experienced by people who economically can not meet their needs appropriate to the standard of living in an area. There were some fisherman, community members who live in Sumber Jaya Municipal, have no assets such as land and housing, so they forced renting a homestay. This research were aimed to elaborate the characteristics of poverty and to analyze structural factors which formed the poverty that occured in the community. This research was conducted by applying qualitative method. Meanwhile, collecting data employed techniques such as field observation, indepth interview to some key informants, and studied the documents which were relevant
\end{abstract}


with the research. The results revealed that the characteristics of fisherman community poverty could be traced from slum area conditions, the lower access to health services, the lower education level, and the bad household economic conditions i.e uncertain income, lesser productive asset, and economically dependent to the skipper. The structural factors affecting the poverty came from the relations of production, the system of social relations, the government policies, and other catagories.

Keywords: structural poverty, fisherman community, Bengkulu

\section{PENDAHULUAN}

Kemiskinan pada dasarnya merupakan masalah dalam pembangunan yang bersifat multidimensional dan berkaitan erat dengan aspek sosial, ekonomi, dan budaya. Mereka yang tergolong miskin umumnya sulit untuk melepaskan diri dari jerat kemiskinan, karena kemiskinan telah berkembang menjadi sebuah bentuk kemiskinan yang bukan hanya mengalami kekurangan materi, tetapi juga unsur-unsur kemiskinan lain didalammya, yang menyatu dengan kehidupan mereka (Soedjatmoko, 1984; Suyanto, 2001). Kemiskinan secara struktural biasanya diderita oleh golongan petani yang tidak memiliki lahan atau buruh nelayan yang tidak memiliki kapal lalu hidup dengan berhutang kepada juragan pemilik kapal (Kasim, 2006).

Terkait dengan kemiskinan, berbagai pandangan umum menyatakan bahwa kemiskinan umumnya bersifat struktural dan multi dimensional, baik secara politik, sosial, ekonomi, maupun budaya. Setiadi (2006) misalnya mengemukakan banyak dimensi yang memunculkan kemiskinan. Dimensi-dimensi ini ditenggarai juga sebagai penyebab lahirnya kemiskinan di masyarakat, seperti tidak dimilikinya wadah organisasi yang mampu memperjuangkan aspirasi dan kebutuhan masyarakat miskin. Kemudian mereka tidak terintegrasi ke dalam institusi sosial yang mengakibatkannya teralienasi dari dinamika masyarakat. Selain itu secara klasikal, rendahnya penghasilan mengakibatkan ketidakmampuan untuk memenuhi kebutuhan hidup mereka sampai batas yang layak. Terakhir, rendahnya kualitas sumber daya manusia, kurangnya kepemilikan peralatan kerja, modal dana, perumahan, permukiman dan lain-lain.

Kemiskinan struktural sering dilihat sebagai suatu gejala yang tetap di tengahtengah masyarakat (Mardimin, 1996). Soemardjan (1984), misalnya melihat kemiskinan struktural sebagai suatu fenomena yang built-in di mana ada suatu golongan sosial yang menderita kekurangan-kekurangan fasilitas, modal, sikap mental atau jiwa usaha yang diperlukan untuk melepaskan diri dari ikatan kemiskinan itu. Dengan demikian 
kemiskinan struktural mencerminkan gejala ketidakmampuan yang melekat di dalam struktur sosial masyarakat. Widyastuti (2010) menyatakan seorang anak yang dilahirkan di keluarga miskin, besar kemungkinan dia akan menjadi miskin juga.

Terkait dengan kemiskinan nelayan, jeratan kemiskinan struktural merupakan salah satu gambaran penyebab utama kemiskinan. Keadaan kemiskinan struktural yang membelenggu nelayan selama ini tidak mudah untuk diatasi. Menurut Sudarso (2007), kesulitan untuk meningkatkan kesejahteraan nelayan, selain dipengaruhi sejumlah kelemahan internal, juga karena pengaruh faktor eksternal. Keterbatasan pendidikan, kurangnya kesempatan untuk mengakses dan menguasai teknologi yang lebih modern, dan tidak dimilikinya modal yang cukup yang seringkali menyulitkan usaha-usaha untuk memperdayakan kehidupan nelayan. Terbatasnya potensi sumber daya ikan yang yang bisa dimanfaatkan nelayan, persaingan yang makin intensif, mekanisme pasar, posisi tawar nelayan dihadapan tengkulak, keadaan infrastruktur pelabuhan perikanan, dan yuridiksi daerah otonom adalah beban tambahan yang semakin memperparah keadaan nelayan buruh.

Badan Pusat Statistik (2010) mencatat bahwa sebagian besar masyarakat Provinsi Bengkulu yang berusaha di bidang perikanan tangkap masih kurang sejahtera. Hal ini dapat dilihat melalui persentase kemiskinan pada usaha perikanan tangkap berikut (Tabel 1) :

Tabel 1. Persentase Orang Miskin Berdasarkan Lapangan Usaha Perikanan, 2010

\begin{tabular}{clc}
\hline No. & \multicolumn{1}{c}{ Provinsi } & Persentase Kemiskinan (\%) \\
\hline 1. & Bengkulu & 42,80 \\
\hline 2. & Papua & 40,79 \\
\hline 3. & Papua Barat & 40,17 \\
\hline 4. & Maluku & 37,14 \\
\hline 5. & DI Yogyakarta & 30,08 \\
\hline
\end{tabular}
Sumber: Badan Pusat Statistik,2010

Publikasi daring BPS Provinsi Bengkulu yang mendasarkan pada hasil Susenas memperlihatkan adanya penurunan angka kemiskinan di Kota Bengkulu. Perkembangan penduduk miskin di Kota Bengkulu per September 2013 sebesar 21,51\%, kemudian menjadi 20,16\% per September 2014. Selama periode Maret 2015 sampai dengan Maret 2016 juga mengalami penurunan dari $21,14 \%$ ke $20,72 \%$. Namun bila diperhatikan dari tahun 2009, angka kemiskinan mengalami kenaikan yakni dari 17,57\% per Juli 2009 menjadi $17,7 \%$ per Juli 2010. Kemudian meningkat tajam menjadi 22,23\% per 
Kemiskinan Struktural Komunitas Nelayan Di Kelurahan Sumber Jaya.......

September 2011 dan 22,10\% per September 2012. Dalam dokumen Rencana Pembangunan Jangka Menengah Daerah (RPJMD) Kota Bengkulu Tahun 2013-2018, dicantumkan distribusi jumlah Rumah Tangga Miskin di Kota Bengkulu menurut kecamatan seperti tampak pada Tabel 2 berikut :

Tabel 2. Data Rumah Tangga Miskin dan Individu Miskin Kota Bengkulu Per Tahun 2012

\begin{tabular}{lcc}
\hline \multicolumn{1}{c}{ Kecamatan } & Rumah Tangga & Individu \\
\hline 1. Selebar & 3.306 & 14.757 \\
\hline 2. Kampung Melayu & 2.449 & 10.519 \\
\hline 3. Gading Cempaka & 881 & 4.044 \\
\hline 4. Ratu Agung & 2.226 & 10.088 \\
\hline 5. Ratu Samban & 1.193 & 5.116 \\
\hline 6. Singgar Pati & 1.999 & 9.040 \\
\hline 7. Teluk Segara & 1.454 & 6.631 \\
\hline 8. Sungai Serut & 1.251 & 5.608 \\
\hline 9. Muara Bangkahulu & 1.925 & 8.842 \\
\hline \multicolumn{1}{c}{ Total } & $\mathbf{1 6 . 6 8 4}$ & $\mathbf{7 4 . 6 4 5}$
\end{tabular}

Sumber : RPJMD Kota Bengkulu Tahun 2013-2018

Rumah Tangga Miskin dan individu miskin per kecamatan di Kota Bengkulu adalah Kecamatan Selebar, Kecamatan Kampung Melayu, Kecamatan Ratu Agung, Kecamatan Singaran Pati, dan Kecamatan Muara Bangkahulu. Namun demikian jumlah penduduk per kecamatan konsentrasi individu miskin tertinggi berada pada kecamatan Kampung Melayu sebesar 55,02\%, di mana tingkat kemiskinan tertinggi terdapat pada kelurahan Sumber Jaya sebanyak 800 rumah tangga miskin (RPJMD Kota Bengkulu 2013-2018). Penangkapan ikan di Provinsi Bengkulu berpusat pada Pangkalan Pendaratan Ikan (PPI) Pulau Baai yang merupakan pangkalan pendaratan ikan terbesar di Provinsi Bengkulu. Di wilayah ini tercatat jenis-jenis kapal dan alat tangkap yang beroperasi sebagai berikut seperti tampak pada Tabel 3 berikut.

Tabel 3. Jumlah Kapal Penangkapan dan Alat Tangkap di PPI Pulau Baai, Kota Bengkulu 2014

\begin{tabular}{lccc}
\hline \multicolumn{1}{c}{ Ukuran Kapal } & Jumlah Unit & Jenis Alat Penangkapan & Jumlah Unit \\
\hline$<5$ GT & 20 & Pancing & 118 \\
\hline $5-10$ GT & 187 & Gill Net & 131 \\
\hline $10-30$ GT & 34 & Bagan Apung & 13 \\
\hline Motor Tempel & 13 & Purse seine & 12 \\
\hline Perahu Tanpa Motor & 21 & & 274 \\
\hline Jumlah & 275 & &
\end{tabular}

Sumber : Balai Pelabuhan Perikanan (2014) 
Berdasarkan kedudukannya, nelayan yang terdapat di wilayah tersebut terbagi menjadi dua yaitu nelayan yang mempunyai alat-alat produksi untuk menangkap ikan seperti kapal dan alat tangkap, yang biasanya disebut sebagai juragan dan nelayan yang tidak memiliki alat tangkap, disebut nelayan buruh (Satria, 2001; Kusnadi, 2000). Nelayan buruh yang hanya memiliki jasa tenaga, sangat membutuhkan ketersediaan fasilitas untuk mendukung keberlangsungan operasi penangkapan ikan di laut. Sarana perahu atau kapal yang ada di wilayah Pulau Baai cenderung didominasi oleh kapal dengan kapasitas yang besar.

Menurut Kusnadi (2000), faktor penyebab kemiskinan nelayan dapat berupa berupa fluktuasi musim ikan, pada saat tidak musim menangkap ikan nelayan menghadapi kesulitan-kesulitan ekonomi untuk memenuhi kebutuhan sehari-hari. Ketimpangan sistem bagi hasil dan dampak negatif motorisasi, menyebabkan semakin terpuruknya nelayan kecil. Suyanto (2003) menjelaskan bahwa kemiskinan nelayan disebabkan oleh perangkap hutang, irama musim yang tidak menentu seringkali rumah tangga nelayan miskin harus menjual aset produksi untuk memenuhi kebutuhan hidup sehari-hari dan menutupi hutang yang tak kunjung usai.

Kemiskinan yang dialami keluarga nelayan erat kaitannya dengan perubahan iklim dan cuaca yang tidak menentu. Hasibuan et al (2017) misalnya menemukan gejala perubahan alokasi peranan dan ekonomi pada struktur keluarga nelayan di Kota Manna-Bengkulu Selatan akibat perubahan iklim. Demikian juga temuan Pramudyasmono et al (2011), faktor penyebab kemiskinan yang bersifat struktural pada keluarga nelayan di Bengkulu adalah dominasi kapal cantrang dan bagan milik juragan kaya yang menjadi saingan nelayan kecil dalam penangkapan ikan. Sebelum adanya kapal cantrang di sekitar daerah operasi nelayan, penghasilan nelayan kecil cukup melimpah. Kapal cantrang yang dilengkapi dengan alat tangkap modern sangat berpengaruh negatif terhadap hasil tangkap nelayan kecil.

Sebagian besar nelayan yang melakukan transaksi jual-beli di Pelabuhan Pendaratan Ikan (PPI) Pulau Baai berasal dari Kelurahan Sumber Jaya. Masyarakat yang bermata pencaharian nelayan sebanyak 998 orang yang beroperasi di Perairan Bengkulu dan sekitarnya. Kondisi sosial ekonomi masyarakat nelayan di Kelurahan Sumber Jaya jauh dari sejahtera dan bertempat tinggal di lingkungan kumuh. 
Adanya bantuan pemerintah setiap tahun dalam berbagai program bantuan sarana dan prasarana dari pemerintah pusat dan daerah belum menyentuh nelayan buruh. Kondisi nelayan saat ini masih terpuruk dan penghasilan nelayan yang tidak menentu karena hanya bekerja pada pengusaha ikan/pemilik kapal. Berdasarkan latar belakang tersebut, penelitian ini bertujuan untuk menguraikan karakteristik kemiskinan struktural dan menganalisis dimensi struktural yang membentuk kemiskinan di kalangan masyarakat nelayan yang tinggal di Kelurahan Sumber Jaya, Kecamatan Kampung Melayu Kota Bengkulu.

\section{METODE PENELITIAN}

Penelitian ini dilaksanakan di Kelurahan Sumber Jaya Kecamatan Kampung Melayu Kota Bengkulu selama tiga bulan, mulai Januari s.d Maret 2017. Secara purposif, Kelurahan Sumber Jaya dipilih karena merupakan salah satu daerah yang terletak di pesisir lautan Bengkulu, tepatnya di Kawasan Pulau Baai, mayoritas penduduknya bekerja sebagai nelayan dengan alat tangkap beragam mulai dari kecil sampai besar. Data-data dikumpulkan dengan teknik wawancara mendalam, pengamatan, dan studi dokumen (Tabel 4). Informan kunci sebagai sumber utama data penelitian ini yaitu 6 orang ABK, 1 orang nelayan senior dan 1 orang aparat pemerintah Kelurahan Sumber Jaya. Wawancara mendalam dilakukan dengan menggunakan panduan wawancara dan hasil wawancara dilakukan pencatatan selama 1 X 24 jam.

Tabel 4. Jenis-Jenis Data dan Metode Pengumpulannya

\begin{tabular}{|c|c|c|c|}
\hline No & Rincian Data & Sumber Data & Metode \\
\hline 1. & $\begin{array}{ll}\text { Karakteristik Wilayah } \\
- & \text { Jumlah penduduk } \\
\text { - } & \text { Mata Pencaharian } \\
\text { - } & \text { Persebaran penduduk } \\
\text { - } & \text { Komposisi penduduk } \\
- & \text { Kondisi insfrastruktur wilayah } \\
\text { Kondisi penduduk dalam keadaan } \\
\text { miskin }\end{array}$ & $\begin{array}{ll}\text { - } & \text { Monografi } \\
& \text { Kelurahan } \\
\text { - } & \text { Aparatur Kelurahan } \\
\text { - } & \text { tokoh masyarakat }\end{array}$ & $\begin{array}{ll}\text { - } & \text { wawancara } \\
\text { - } & \text { studi } \\
& \text { dokumen } \\
\text { monogrami } \\
\text { kelurahan } \\
\text { - } & \text { pengamatan }\end{array}$ \\
\hline
\end{tabular}




\begin{tabular}{|c|c|c|c|}
\hline No & Rincian Data & Sumber Data & Metode \\
\hline 2. & $\begin{array}{ll}\text { Karakteristik Kemiskinan Struktural } \\
- & \text { Faktor-Faktor penyebab kemiskinan } \\
& \text { nelayan } \\
- & \text { Pola hubungan sosial } \\
- & \text { Akses terhadap fasilitas kesehatan } \\
- & \text { Akses terhadap pendidikan } \\
- & \text { Kondisi tempat tinggal nelayan } \\
- & \text { Bantuan pemerintah } \\
- & \text { Sistem upah } \\
- & \text { Pola hubungan patron klien } \\
- & \text { Sumber pemodalan nelayan } \\
- & \text { Kondisi alat tangkap } \\
- & \text { Pemasaran hasil tangkapan }\end{array}$ & $\begin{array}{ll}- & \text { Informan kunci } \\
\text { nelayan } \\
\text { - } & \text { Informan kunci } \\
\text { aparat kelurahan } \\
\text { - } & \text { Informan kunci } \\
\text { juragan pemilik } \\
\text { kapal } \\
\text { - } & \text { Responden studi } \\
\text { kasus }\end{array}$ & $\begin{array}{ll}\text { - } & \text { wawancara } \\
& \text { mendalam } \\
\text { - } & \text { dokumentasi } \\
\text { - } & \text { pengamatan }\end{array}$ \\
\hline
\end{tabular}

Pengamatan dilakukan di pelabuhan untuk mendapatkan pemahaman tentang kegiatan keberangkatan dan pendaratan kapal nelayan serta di sekitar permukiman tempat tinggal nelayan dan TPI untuk memperoleh pemahaman tentang kegiatan pemasaran hasil tangkapan nelayan. Selanjutnya hasil pengamatan didokumentasikan dalam bentuk foto.

Penelitian ini menerapkan strategi studi kasus, yakni mempelajari kasus-kasus rumah tangga miskin di lokasi penelitian. Dengan menerapkan strategi studi kasus, penelitian bertujuan untuk mengungkapkan sebuah studi yang berkaitan dengan "how" dan “why”(Yin, 2014). Studi kasus dilakukan terhadap 1 rumah tangga Anak Buah Kapal (ABK) kapal Pancing, 1 rumah tangga ABK kapal Jaring, dan 1 rumah tangga ABK kapal cantrang. Responden kasus penelitian ini merupakan rumah tangga nelayan buruh yang memiliki riwayat hidup sebagai rumah tangga miskin menurut keterangan informan kunci. Selain itu mereka terverifikasi di lapangan oleh peneliti dengan menilai aspek pendapatan rumah tangga, kepemilikan aset ekonomi, kondisi kesehatan, dan perumahan yang ditinggalinya.

Dengan mendasarkan pada teknik pengumpulan data dan studi kasus tersebut, selanjutnya data-data yang terkumpul dianalisis dengan model interaktif sebagaimana dikembangkan oleh Miles dan Huberman (1992), di mana data-data direduksi, disajikan, dan dilakukan penarikan kesimpulan. Tiga aktivitas analisis data ini dilakukan secara berkesinambungan sejak data dikumpulkan di lapangan. 


\section{PEMBAHASAN}

\section{Karakteristik Kemiskinan Komunitas Nelayan di Kelurahan Sumber Jaya}

Karakteristik kemiskinan umumnya dapat dilihat dari kondisi kehidupan seharihari yang dialami oleh masyarakat yang tergolong miskin (Tabel 5). Beberapa karakteristik yang menunjukkan terjadinya gejala-gejala kemiskinan di komunitas nelayan adalah kondisi pendidikan, akses terhadap kesehatan, kondisi tempat tinggal yang kumuh, dan pendapatan nelayan yang rendah yang kemudian membuat mereka mengalami kemiskinan.

Tabel 5. Karakteristik Kemiskinan Komunitas Nelayan di Kelurahan Sumber Jaya

\begin{tabular}{|c|c|c|}
\hline No & Kondisi & Karakteristik \\
\hline \multirow{5}{*}{1.} & \multirow{5}{*}{ Kondisi Rumah Nelayan } & - $\quad$ Rumah semi permanen \\
\hline & & - $\quad$ Status masih menyewa/mengontrak \\
\hline & & $\begin{array}{l}\text { - Dihuni oleh buruh nelayan dan masyarakat pada golongan } \\
\text { ekonomi rendah }\end{array}$ \\
\hline & & - $\quad$ Lahan permukiman sengketa dengan Pelindo II \\
\hline & & - Kepemilikan rumah kontrakan dikuasai oleh juragan \\
\hline \multirow{2}{*}{2.} & Kondisi Kesehatan Nelayan & - Jika sakit membeli obat di warung \\
\hline & & - $\quad$ Tidak mengurus kartu KIS karena kesibukan sehari-hari \\
\hline \multirow[b]{2}{*}{3.} & \multirow[b]{2}{*}{ Kondisi Pendidikan } & - $\quad$ Pendidikan buruh nelayan umumnya masih rendah \\
\hline & & $\begin{array}{l}\text { - Anak nelayan jarang atau tidak ada yang melanjutkan } \\
\text { pendidikan ke tingkatan Perguruan Tinggi }\end{array}$ \\
\hline \multirow{3}{*}{4.} & \multirow{3}{*}{$\begin{array}{l}\text { Keadaan Ekonomi Rumah } \\
\text { Tangga Nelayan }\end{array}$} & - Pendapatan tidak menentu \\
\hline & & $\begin{array}{l}\text { - Tidak memiliki aset produktif seperti ternak atau lahan } \\
\text { untuk bertani }\end{array}$ \\
\hline & & $\begin{array}{l}\text { - Meminjam pada juragan jika tidak memiliki uang untuk } \\
\text { memenuhi kebutuhan sehari-hari }\end{array}$ \\
\hline
\end{tabular}

Sumber: Data primer diolah, 2017

Kemiskinan di kalangan nelayan buruh di Kelurahan Sumber Jaya sudah berlangsung sejak lama. Penduduk miskin umumnya merupakan masyarakat pendatang. Mereka tidak memiliki aset berupa lahan dan tempat tinggal, sehingga banyak dari mereka yang memilih menyewa rumah bedengan dengan ukuran 3,5 X 6 m. Rumah kontrakan ini kebanyakan adalah milik juragan pemilik kapal, di mana nelayan bekerja. Kondisi rumah hanya terbuat dari papan, dan dengan lantai semen. Biaya sewa yang harus dibayar berkisar antara Rp100.000 s.d Rp 300.000 per bulan untuk satu bedengan atau Rp 3.500.000 per tahun.

Tata letak dan keteraturan bangunan sebagian besar sudah terlihat teratur dengan letak yang sudah menghadap akses jalan dan gang yang ada. Pada bagian tengah blok, 
banyak bangunan masih tidak teratur. Banyak bangunan yang tidak teratur dan beragam arahnya, terutama pada bagian tengah blok bangunan dan tepi air. Kepadatan bangunan pada kawasan ini relatif tinggi bila dibandingkan wilayah lain di kelurahan Sumber Jaya. Sebagian besar jalan belum di aspal, bagian jalan yang sudah di aspal hanya pada bagian muka dari beberapa gang. Dari hasil pengamatan maka dapat dikatakan bahwa hampir seluruh akses jalan di Kelurahan Sumber Jaya memerlukan perbaikan. Selain akses jalan darat, Kelurahan Sumber Jaya juga dapat diakses melalui air, yaitu melalui Sungai Bangkahan. Di sisi sungai terdapat beberapa dermaga yang menjadi tempat nelayan menambatkan kapal-kapalnya.

Hampir sebagian besar permukiman nelayan buruh tidak dilayani oleh jaringan drainase, baik untuk air hujan maupun air limbah. Jaringan drainase hanya terdapat pada pada bagain-bagian rumah yang dilaluinya. Dengan kondisi ini maka jika terjadi musim hujan pada beberapa titik akan terdapat genangan air.

Kondisi kawasan pemukiman secara umum terkesan kumuh selain karena kepadatan rumah dan kualitas drainase, juga karena belum terlayani oleh sistem kebersihan lingkungan perkotaan. Sebagian besar masyarakat masih membuang sampah ke sungai, yang terlihat dari kondisi tepian sungai yang dipenuhi dengan sampah. Untuk kawasan kumuh masih ada bangunan pada kawasan kumuh yang tidak memiliki jamban dan septic tank, sehingga masih ada masyarakat yang menjadikan sungai sebagai tempat pembuangan/kakus. Sama halnya dengan saluran limbah, masih terdapat hunian yang saluran pembuangan limbahnya tidak menyatu dengan saluran pembuangan utama, sehingga sering terlihat kondisi di mana ada area yang tergenang oleh air limbah.

Ciri lain dari kemiskinan nelayan yaitu kesehatan. Tingkat kesehatan nelayan di Kelurahan Sumber Jaya umumnya masih rendah. Biasanya masyarakat hanya membeli jenis obat yang dijual di warung sekitar rumah jika mengalami sakit atau memeriksakan diri di Puskemas yang ada di Kelurahan Sumber Jaya. Belum semua rumah tangga miskin nelayan memiliki Kartu Indonesia Sehat dari Badan Penyelenggara Jaminan Sosial (BPJS) -masyarakat menyebutnya kartu BPJS. Hal ini terjadi karena nelayan buruh merasa tidak sempat untuk mengurusnya ke Kelurahan. Selain itu akibat masih adanya kesalahan dalam pendataan penduduk miskin.

Umumnya pendidikan kepala rumah tangga nelayan miskin hanya mencapai pendidikan Sekolah Menengah Pertama (SMP). Inilah yang menyebabkan tidak adanya 
peluang untuk bekerja di sektor lain selain menjadi nelayan, meskipun pekerjaan sebagai nelayan beresiko tinggi terhadap keselamatan mereka. Anak-anak nelayan miskin umumnya sudah mencapai Sekolah Menengah Atas (SMA). Adanya program wajib belajar dari pemerintah dirasa meringankan biaya pendidikan. Hanya sedikit keluarga nelayan yang mencoba bertekad untuk menyekolahkan anaknya ke jenjang pendidikan tinggi. Anggapan pendidikan tinggi atau kuliah membutuhkan biaya tinggi menyebabkan deprivasi diri yang semakin jauh, ditilik dari kemampuan nelayan miskin untuk membiayai anak-anaknya.

Umumnya rumah tangga nelayan tidak mempunyai aset produktif lain seperti lahan untuk bertani atau hewan peliharaan seperti sapi/kerbau. Aset lain seperti kendaraan bermotor juga tidak mereka miliki kalaupun ada kendaraan dibeli secara kredit, untuk memudahkan dalam perjalanan sehari-hari nelayan. Salah satu mata pencaharian rumah tangga nelayan adalah sebagai penjemur ikan asin. Kegiatan ini dilakukan oleh istri nelayan untuk menambah penghasilan untuk memenuhi kebutuhan hidup.

\section{Dimensi Kemiskinan Struktural Nelayan}

\section{Pola Hubungan Produksi}

Pola hubungan produksi merujuk pada konsep labor relation sebagaimana dikenal dalam analisis Marxist tentang hubungan seputar penggunaan alat-alat produksi (means of production) (Satria 2001, Stzompka 2004). Alat produksi dipandang sebagai suatu kekuatan (force of production) yang mampu menjadi media terciptanya hubungan penguasaan pemilik alat produksi terhadap pekerja. Dalam konteks hubungan pada komunitas nelayan, pola hubungan produksi merupakan pola hubungan kerja yang terjadi antara juragan pemilik kapal dan nelayan buruh yang dilihat dari pola pembagian kerja dan pembagian hasil penangkapan.

\section{Teknologi Penangkapan dan Sistem Pembagian Kerja}

Untuk sektor perikanan tangkap alat produksi terdiri dari armada kapal dan alat tangkapnya. Kemajuan teknologi akan meningkatkan hasil tangkap, sehingga akan meningkatkan menaikan taraf kehidupannya. Berikut tabel karakteristik armada dan alat tangkap kapal berdasarkan jenis kapal yang dipergunakan nelayan. 
Tabel 6. Karakteristik Armada dan Alat Tangkap Kapal di Kelurahan Sumber Jaya

\begin{tabular}{|c|c|c|c|c|}
\hline No. & Karakteristik & Kapal Pancing & Kapal Jaring & Kapal Cantrang \\
\hline 1. & Konstruksi Kapal & $\begin{array}{c}\text { Badan kapal dari } \\
\text { bahan kayu }\end{array}$ & $\begin{array}{c}\text { Badan kapal dari } \\
\text { bahan kayu }\end{array}$ & $\begin{array}{c}\text { Badan kapal dari } \\
\text { bahan kayu }\end{array}$ \\
\hline & Ukuran kapal & $5 \times 2$ meter & $5 \times 2$ meter & $4 \times 1$ meter \\
\hline 3. & Jenis alat tangkap & Pancing & Jaring & $\begin{array}{l}\text { Jaring (pukat } \\
\text { harimamu) }\end{array}$ \\
\hline & $\begin{array}{l}\text { Ukuran Mesin } \\
\text { Kapal }\end{array}$ & $10 \mathrm{GT}$ & $10 \mathrm{GT}$ & $5-10 \mathrm{GT}$ \\
\hline 5. & $\begin{array}{l}\text { Penggunaan } \\
\text { satelit }\end{array}$ & Ada & Ada & $\begin{array}{l}\text { Belum (hanya } \\
\text { GPS) }\end{array}$ \\
\hline 6. & $\begin{array}{l}\text { Lama } \\
\text { Pengoperasian }\end{array}$ & $<10$ hari & $<10$ hari & Hanya satu hari \\
\hline & Hasil tangkap & Maksimal 1 ton & Maksimal 1 ton & $100 \mathrm{~kg}$ \\
\hline 8. & Bahan bakar & Solar & Solar & Solar \\
\hline
\end{tabular}

Sumber: Wawancara informan kunci, 2017

Sebagaimana penemuan Wijayanti (2008) tentang hubungan kerja nelayan di Pati-Jawa Tengah lebih menekankan pada pemenuhan hak dan kewajiban antara juragan dan pekerjanya. Peranan juragan adalah menginvestasikan kapital dalam bentuk armada kapal dan alat tangkap sedangkan nelayan buruh yang mengoperasikannya.

Kapal pancing yang ada di Kelurahan Sumber Jaya berukuran kecil dengan awak kapal 5-6 orang dengan waktu pengoprasian sekitar 10 hari. Pemimpin pekerjaan dan pengemudi kapal adalah tekong, sedangkan sisanya diurus oleh semua ABK yang mengerjakan hampir seluruhnya pekerjaan yang ada. Pekerjaan seperti pengisian bahan bakar, proses penangkapan ikan menggunakan pancing, pengisian es, sampai pengangkutan ikan ke darat.

ABK pada kapal pancing umumya relatif sedikit, karena itu cukup dikontrol oleh satu orang saja selama melaut yaitu tekong. ABK biasanya orang-orang suku Madura dan suku Bugis, karena mereka merupakan juragan pemilik kapal pancing di Kelurahan Sumber Jaya. Kapal yang juragannya suku Madura memiliki tekong dari suku Madura juga, kemudian tekong akan memilih ABK nya jika ada mereka dari suku Madura juga. Namun tidak selalu demikian, hal ini terjadi hanya jika memang ada ABK atau tekong yang suku Madura, karena mereka merasa lebih nyaman bekerja dengan ABK yang bersuku sama. 
Struktur pengorganisasian pada kapal jaring dan kapal pancing umumnya sama. Jumlah ABK pada kapal jaring 4-5 orang dengan satu orang sebagai pemimpin kapal yaitu tekong. Lamanya proses melaut pada kapal jaring berkisar 10 hari tergantung hasil tangkapan dan cuaca selama melaut. Pembagian kerja untuk ABK relatif sama mulai dari proses pengisian bahan bakar, pemuatan bekal untuk melaut sampai penyortiran ikan dilakukan seluruhnya oleh ABK.

Struktur pengorganisasian pada kapal cantrang juga hampir sama, yaitu dipimpin oleh satu orang tekong. Jumlah ABK pada kapal cantrang 3-4 orang. Lama nya proses melaut pada pada umumnya sehari semalam namun ada juga yang lebih tergantung pada jenis kapal dan juragan pemiliknya. ABK melakukan aktivitas mulai dari proses pengisian bahan bakar, pemuatan bekal untuk melaut dan penyortiran ikan.

Ketergantungan nelayan pada teknologi dalam hal penangkapan ikan cukup tinggi. Tempat mereka mencari penghasilan merupakan tempat luas yang sifatnya mudah berpindah dari satu tempat ke tempat lain, dan ikan yang ada di laut tidak dapat ditentukan lokasinya. Para nelayan akan selalu berusaha untuk memaksimalkan teknologi yang digunakan untuk meningkatkan penghasilannya. Teknologi yang yang paling efektif dan efisien merupakan impian dari setiap nelayan. Nelayan yang mempunyai modal besar akan mampu membeli alat tangkap yang lebih bervariasi dan meningkatkan kualitas alat tangkapnya. Namun kasusnya berbeda bagi nelayan buruh yang justru tidak memiliki modal untuk membeli alat tangkap, sehingga harus bekerja kepada orang lain.

Pada umumnya nelayan masih mengalami keterbatasan teknologi penangkapan berupa alat tangkap yang masih sederhana. Wilayah operasi juga masih terbatas, ditambah lagi dengan faktor alam, nelayan sangat tergantung kepada kondisi alam dan musim, sehingga tidak semua nelayan dapat turun melaut. Akibatnya selain hasil tangkap yang rendah, dengan kondisi teknologi yang terbatas membuat nelayan tidak dapat turun melaut dan mereka tidak memiliki penghasilan.

Teknologi yang sederhana mengakibatkan timbulnya persaingan, karena sifat dari sektor perikanan yang merupakan milik umum. Hal ini akhirnya memunculkan pemikiran bahwa sumberdaya yang ada berhak dimiliki oleh siapa saja sehingga siapa saja bisa mengeksplorasinya. Teknologi yang sederhana membuat hasil tangkap tidak 
menentu, ditambah sistem bagi hasil yang cenderung kurang menguntungkan bagi nelayan buruh.

\section{Sistem Bagi Hasil}

Sistem bagi hasil merupakan kegiatan pembagian hasil penjualan ikan dari hasil tangkap setelah nelayan melaut. Sistem bagi hasil ini dipilih sebagai cara pembagian hasil karena adanya perbedaan yang tidak menentu pada setiap kali proses penangkapan ikan di laut. Dengan memperhatikan sistem bagi hasil, dapat diperoleh informasi siapa yang mendapatkan bagian besar dan siapa yang kecil.

Proses bagi hasil akan dilakukan setelah proses penjualan hasil tangkap selesai. Hasil penjualan tidak langsung dibagi, namun akan dipotong biaya perbaikan kapal dan perbekalan selama melaut. Setelah pemotongan biaya tersebut, kemudian akan dilakukan pembagian hasil. Aturan yang ada dalam sistem pembagian hasil untuk menentukan besarnya pendapatan dan bagian yang terlibat dalam hubungan kerja, yaitu:

1. Jumlah keseluruhan uang penghasilan penjualan ikan dalam satu kali melaut dipotong biaya perawatan kapal dan perbekalan atau biaya operasional selama melaut. Besarnya biaya ini tergantung dari lamanya melaut, yakni berkisar antara Rp 750.000 sampai Rp 8.000.000. Biaya ini mencakup biaya solar, es, umpan, makanan untuk perbekalan selama melaut dan rokok. Biaya perbekalan itu terlebih dahulu ditanggung oleh pemilik kapal. Setelah kegiatan melaut selesai biaya perbekalan akan dibayar dari penjualan hasil tangkap.

2. Setelah dipotong biaya perawatan kapal (untuk kapal pancing dan kapal cantrang $10 \%$, kapal jaring 15\%), selanjutnya dipotong biaya perbekalan melaut (makanan). Setelah itu dibagi antara juragan dengan nelayan buruh, di mana pada kapal pancing dan jaring pemilik kapal dan nelayan buruh masing-masing mendapatkan $50 \%$ sedangkan pada kapal cantrang pemilik kapal mendapatkan $60 \%$ dan nelayan buruh $40 \%$.

3. Dari keseluruhan bagian nelayan buruh tersebut, dibagi sesuai dengan besarnya bagian yang harus diterima masing-masing buruh nelayan sesuai perannya selama melaut (tekong mendapatkan 2 bagian, ABK mendapatkan 1 bagian).

4. Bagian yang diterima oleh $\mathrm{ABK}$ tersebut kemudian dibagi rata kepada setiap $\mathrm{ABK}$, sesuai dengan jumlah ABK yang terlibat dalam penangkapan ikan. 
Pembagian hasil ini hanya dapat dilakukan jika pendapatan hasil penjualan ikan sudah melampaui biaya perbekalan selama melaut. Jika pendapatan selama melaut tidak melebihi biaya perbekalan maka seluruh beban perbekalan yang telah dikeluarkan oleh pemilik kapal ditanggung sendiri oleh ABK. Itulah yang kemudian menjadi hutang nelayan buruh kepada pemilik kapal.

Sistem bagi hasil yang berlaku di dikalangan nelayan buruh adalah sistem bagi hasil menurut hasil tangkapan. Hal ini dilakukan karena hasil tangkap yang tidak menentu dan juga pengaruh dari keadaan alam. Alam menjadi penentu utama pendapatan nelayan, jika cuaca mendukung maka nelayan dapat melaut jika terjadi badai maka nelayan dapat menganggur hingga berbulan-bulan lamanya. Akibat dari keadaan ini sangat berpengaruh terhadap hasil tangkapan nelayan.

Sebagaimana ditemukan oleh Damayanti et al (2018), pola hubungan produksi nelayan berubah seiring dengan tahapan modernisasi. Di mana tahapan modernisasi identik dengan dominasi jenis armada tertentu. Namun pola bagi hasil tidak begitu mengalami perubahan. Menurut sistem bagi hasil ini, maka pihak yang paling sedikit mendapatkan bagian dari hasil penangkapan adalah ABK. Jumlah ABK berkisar antara 3-5 orang pada setiap kapal hanya mendapatkan 1 bagian dari pembagian antara pemilik kapal, tekong, dan ABK. Dengan demikian dapat dimengerti apabila penghasilan keluarga ABK adalah yang paling kecil dan seringkali untuk memenuhi kebutuhan hidupnya nelayan $\mathrm{ABK}$ harus meminjam uang kepada juragan pemilik kapal, terutama pada saat musim badai. Di sinilah para nelayan memiliki ketergantungan pada juragan cukup tinggi.

Penelitian ini menemukan bahwa sistem bagi hasil yang berlaku dipandang lebih menguntungkan pemilik kapal dan sebaliknya merugikan nelayan buruh. Biaya perawatan dapat disetarakan dengan biaya sewa kapal. Sedangkan bagian yang diperoleh pemilik kapal adalah keuntungan dari usaha penangkapan ikan yang dilakukan oleh nelayan buruh (tekong dan ABK). Pada sisi lain, biaya perbekalan dianggap sebagai hutang nelayan buruh kepada pemilik kapal. Adapun bagian yang diterima nelayan buruh merupakan sisa jerih payah usahanya melakukan penangkapan di laut. 


\section{Pola Hubungan Sosial: Sistem Patron Klien}

Keadaan alam yang tidak menentu membuat hasil tangkap yang diperoleh nelayan juga tidak menentu serta tidak adanya kerja sampingan ketika musim badai atau paceklik datang membuat beberapa nelayan terpaksa meminjam uang kepada juragan untuk memenuhi biaya logistik melaut dan kebutuhan hidup sehari-hari.

Sistem hubungan sosial antara juragan dengan juragan terlihat pada kerjasama dalam penetapan sistem bagi hasil yang berlaku untuk setiap alat tangkap di mana sistem bagi hasil pada umumnya sama. Selain dalam hal peminjaman modal, juragan juga memperbesar pengaruhnya melalui penguasaan atas kapal dan peralatan kerja, serta distribusi hasil tangkap.

Pengaruh juragan sangat besar dalam menguasai kehidupan sosial ekonomi di komunitas nelayan perlahan telah mengikat nelayan melalui kontrak kerja di mana setiap hasil tangkap dikelola oleh juragan yang telah meminjamkan modal, alat tangkap dan kapal pada nelayan buruh, sehingga terbangunlah hubungan patron klien di mana juragan sebagai patron memberikan modal yang dibutuhkan kepada nelayan buruh (klien) selama melaut.

Hubungan kerja antara juragan dan nelayan buruh terjalin dengan adanya komunikasi atau adanya hubungan kerabat dan kerjasama antara mereka. Hubungan kerjasama di mana juragan merangkap sebagai pemilik kapal melakukan hubungan kerja berdasarkan kemampuan dan keterampilan dalam hal melaut yang dimiliki oleh nelayan buruh. ABK kapal dipilih langsung oleh tekong atau kapten kapal yang sudah dipercayai oleh $\mathrm{ABK}$ sebagai pemimpin mereka. Sistem pemilihan anggota ABK tidak rumit mereka hanya dihubungi oleh tekong jika akan melaut.

Pada umumnya juragan juga ikut melaut jika tidak ada tekong yang membawa kapal, ini dilakukan agar kapal tidak menganggur lama di pelabuhan karena dapat merusak kondisi kapal. Juragan sebagai pemilik kapal dan alat-alat tangkap serta modal membutuhkan tenaga kerja untuk proses penangkapan ikan, dan buruh atau ABK menyediakan tenaga dengan harapan menerima upah. Nelayan buruh pada umumnya menggantungkan hidupnya pada juragan pemilik modal, terutama saat musim badai atau laut pasang yang mengakibatkan mereka tidak pergi melaut.

"Lantaran saya ini sudah ada sangkutan sama bos dek ya gak enak, jadi kalau mau pindah itu gak enak harus bayar dulu pinjaman itu, nah itulah kayak gitu gak bisa. Kecuali kita sudah lunas dulu nah itu baru bisa, di darat ini juga gak ada kerjaan yah 
kalau gak melaut apa mau dimakan yah harus pinjam dulu sama bos cak itulah terikat jadinya dek. Nanti kalau sudah melaut dipotong dari hasil melaut itu pun kalau cukup untuk bekal, kalau tidak ya jadi nambah hutang sama bos" (Wawancara $A W, 10 / 02 / 2017)$

Pola hubungan ini sudah berlangsung sangat lama dan terus-menerus. Hubungan yang didasarkan akibat dari adanya pinjaman uang yang besarnya tergantung kepada jumlah yang dipinjam oleh nelayan pada juragan-nya. Pinjaman uang tersebut tidak perlu dibayar selama buruh nelayan masih bekerja pada juragan yang bersangkutan. Jika buruh nelayan masih memiliki pinjaman pada juragan tersebut maka ia tidak diperbolehkan bekerja dengan juragan lain. Jika ingin bekerja dengan juragan lain maka buruh nelayan tersebut harus mengembalikan uang yang dipinjam kepada juragan semula.

Menurut Sinaga et al (2015), juragan berperan sebagai patron karena memiliki kekuatan, kekayaan dan pengaruh terhadap nelayan pemilik kapal sedangkan nelayan pemilik kapal berperan sebagai klien karena menerima pengaruhi dari patron. Menurutnya hubungan patron-klien ini bersifat saling menguntungkan dan cenderung bertahan dalam jangka waktu panjang dikarenakan kekuatan posisi patron yang menyebabkan posisi klien menjadi terikat.

Bagi para nelayan buruh, terjalinnya hubungan dengan juragan, merupakan suatu hal penting dalam menjaga kelangsungan hidupnya. Tidak adanya lembaga keuangan yang dapat memberikan pinjaman kepada nelayan buruh menimbulkan permasalahan ekonomi. Keadaan nelayan pada hubungan patron klien berada pada posisi paling lemah dan cenderung tidak mampu memenuhi kebutuhan hidup tanpa bantuan juragan. Dalam kondisi ini nelayan berada pada posisi di mana perannya sangat kecil, dengan tidak mampunya memenuhi kebutuhan sendiri tanpa adanya bantuan dari juragan. Sebaliknya juragan berada pada posisi sangat kuat di mana selain sebagai penyedia modal, juragan juga pemilik kapal yang mempunyai kekuasaan dalam hubungan patron klien.

\section{Masalah Kebijakan Pemerintah}

\section{Kartu Nelayan}

Kartu nelayan merupakan salah satu kebijakan pemerintah sebagaimana tertuang dalam Peraturan Menteri Kelautan dan Perikanan Republik Indonesia Nomor 
16/Permen-KP/2016 tentang kartu nelayan. Kartu nelayan ini sebenarnya mirip dengan Kartu Tanda Penduduk (KTP) di mana fungsinya adalah sebagai bukti bahwa penerima kartu pekerjaan utamanya adalah nelayan dan melakukan kegiatan produktif dalam memproduksi dan mengelola sumber daya perikanan.

Kartu Nelayan ini juga berfungsi sebagai identitas yang dipergunakan apabila ada bantuan dari pemerintah. Dengan kartu ini nelayan dapat mendapatkan hak yang sudah ditetapkan pemerintah bagi nelayan. Kartu ini juga dapat dipergunakan untuk melakukan klaim asuransi kecelakaan. Apabila terjadi kecelakaan kerja selama melaut maka dengan adanya kartu ini nelayan akan mendapat bantuan dana pengobatan dan asuransi jiwa bila terjadi kecelakaan di laut yang mengakibatkan kematian. Namun asuransi hanya berlaku bila nelayan mengalami kecelakaan saat bekerja di laut.

Menurut nelayan, asuransi hanya berlaku jika terjadi kecelakaan selama melaut, sebenarnya kebijakan ini kurang tepat. Karena jika terjadi kecelakaan saat tidak melaut maka mereka tidak akan mendapatkan asuransi kecelakaan. Penggunaan kartu nelayan ini belum dapat dirasakan manfaatnya oleh nelayan buruh.

"Ado dek kartu nelayan itu, tapi ya buat apa kan kami tidak berharap di laut itu keccelakaaan. Siapo yang mau mati dilaut, kan dak ado. Kalau pun ado bantuan dari pemerintah untuk alat-alat tangkap itu saya tidak pernah dapat biarpun saya sudah punya kartu nelayan" (Wawancara AW,17/02/2017).

Keberadaan kartu nelayan ini kemudian banyak disalahgunakan oleh masyarakat lain yang sebenarnya pekerjaan utamanya bukan nelayan. Akibatnya tak jarang nelayan yang seharusnya mendapatkan bantuan justru mereka yang bukan bekerja sebagai nelayan.

\section{Pembangunan Rumah Nelayan}

Rumah khusus nelayan yang berada di Kelurahan Sumber Jaya sudah ada sejak tahun 2003. Masyarakat yang bekerja sebagai nelayan khususnya masyarakat yang bermigrasi ke kawasan Pulau Baai tidak memiliki tempat tinggal dan hidup dengan menyewa rumah milik orang lain. Keadaan ini yang akhirnya membuat pemerintah khususnya Dinas Kelautan dan Perikanan Kota Bengkulu membuat kebijakan bantuan rumah untuk nelayan (Tabel 7) : 
108 I Eine Yamitha Pinem, Septri Widiono, Irnad

Kemiskinan Struktural Komunitas Nelayan Di Kelurahan Sumber Jaya.......

Tabel 7. Karakteristik Rumah Bantuan Untuk Nelayan

\begin{tabular}{clccc}
\hline No. & Karakteristik & $\begin{array}{c}\text { Rumah } \\
\text { Bantuan 1 }\end{array}$ & $\begin{array}{c}\text { Rumah } \\
\text { Bantuan 2 }\end{array}$ & $\begin{array}{c}\text { Rumah } \\
\text { Bantuan 3 }\end{array}$ \\
\hline 1. & Tahun dihuni & 2007 & 2016 & Belum dihuni \\
\hline 2. & $\begin{array}{l}\text { Pihak yang } \\
\text { bertanggung } \\
\text { jawab }\end{array}$ & $\begin{array}{c}\text { Dinas Kelautan } \\
\text { dan Perikanan } \\
\text { Kota Bengkulu }\end{array}$ & $\begin{array}{c}\text { Dinas Pekerjaan } \\
\text { Umum Kota } \\
\text { Bengkulu }\end{array}$ & $\begin{array}{c}\text { Dinas Pekerjaan } \\
\text { Umum Kota } \\
\text { Bengkulu }\end{array}$ \\
\hline 3. & $\begin{array}{l}\text { Kondisi fisik } \\
\text { bangunan }\end{array}$ & Semi permanen & Semi permanen & Permanen \\
\hline 4. & $\begin{array}{l}\text { Jumlah bangunan } \\
\text { rumah }\end{array}$ & 20 unit & 50 unit & 52 unit \\
\hline
\end{tabular}

Sumber: Wawancara informan kunci, 2017

Pada dasarnya kebijakan pembangunan rumah dikhususkan bagi nelayan, dengan tujuan agar nelayan yang tidak memiliki rumah dan sudah lama hidup mengontrak rumah, dapat memiliki rumah. Namun sebagian penghuni rumah bukan berasal dari masyarakat yang bekerja sebagai nelayan. Salah satu yang menerima rumah yang berasal dari pekerjaan nelayan akibat dari adanya bencana alam tanah longsor di Kelurahan Sumber Jaya. Bencana ini kemudian merusak beberapa rumah masyarakat. Oleh pihak kelurahan, masyarakat yang rumahnya rusak akibat bencana tanah longsor dipindahkan ke rumah bantuan khusus nelayan. Meskipun pekerjaannya bukan nelayan, namun akibat dari tanah longsor yang menghancurkan rumah mereka, mereka kemudian mendapatkan bantuan rumah

Sebagian besar yang menerima rumah adalah mereka yang memang matapencaharian utamanya adalah nelayan, namun beberapa rumah memang dihuni oleh masyarakat bukan nelayan. Rumah ini juga ada yang dihuni oleh dua keluarga dalam satu rumah. Rumah yang didapatkan oleh masyarakat yang bekerja sebagai nelayan dihuni juga oleh rumah tangga anaknya yang pekerjaanya bukan nelayan. Hal ini disebabkan karena kondisi ekonomi masyarakat yang lemah membuat banyak rumah tangga tidak memiliki rumah dan akhirnya ikut menumpang bersama orang tuanya.

"Ada jugo dek yang nyelip satu dua rumah, seperti yang di belakang kami ini dia kerjanya satpam, tapi karena longsor yang di RT 12 dia dipindahkan sama Kelurahan kesini. Memang bukan nelayan tapi karna rumahnyo la hancur kena longsor disini diueuskan sama orang Kelurahan" (Wawancara TM, 11/03/2017).

"Iyo dek, ntah ngapo bisa dapat yang ini, mungkin dia ngurusnya ke Kelurahan. Kan banyak jugo memang nelayan tapi idak dak ngurus apo dak tau caro ngurusnya. Jadi orang-orang ini ngurus dio lah yang mungkin dapat. Ada jugo 
dek yang nelayan kerjanyo tapi sesekali aja, malam dio nangkap-nangkap udang siangnyo kerjanya berkebun, apa jualan gitu. “ (Wawancara HY, 11/03/2017).

\section{Dimensi Lain Penyebab Kemiskinan Struktural}

\section{Kepemilikan Modal}

Adanya keterbatasan dalam modal finansial yang tidak mereka miliki mengakibatkan nelayan buruh tidak mampu untuk melakukan usaha penangkapan atau usaha lain yang dapat menguntungkan. Akses terhadap lembaga keuangan seperti perbankan sangat sulit bagi nelayan. Syarat yang sulit seperti melampirkan sertifikat rumah padahal nelayan sebagian besar tidak memiliki rumah, serta jaminan seperti Buku Pemilikan Kendaraan Bermotor (BPKB) tidak dimiliki nelayan.

Penghasilan nelayan yang tidak menentu setiap harinya membuat pihak perbankan sulit memberikan pinjaman kepada nelayan. Pihak bank yang memiliki prosedur dan aturan yang sulit untuk dipenuhi oleh nelayan menjadi penghalang ketika mengajukan pinjaman. Ketika terjadi musim badai atau hasil tangkap tidak dapat memenuhi kebutuhan maka nelayan akan meminjam kepada juragannya, yang justru semakin hari akan semakin menjerat nelayan pada kungkungan lingkaran kemiskinan.

Jika dibandingkan meminjam kepada perbankan, meminjam kepada juragan memang relatif mudah. Nelayan tidak harus membuat surat perjanjian atau dikenakan bunga, peminjaman cukup dilakukan secara lisan. Namun konsekuensinya nelayan buruh tersebut tidak dapat bekerja dengan orang lain sampai hutang yang ada pada juragan lunas dibayar. Jeratan hutang yang kemudian setiap hari hingga bertahun-tahun terus berputar, akibatnya nelayan buruh harus menggantungkan hidupnya pada juragan. Mereka kemudian sulit untuk dapat lepas dari struktur hubungan ini. Peluang bekerja di luar nelayan buruh pun menjadi seolah-olah tertutup.

"Kalau untuk makan ya cukupan la, kadang-kadang sebulan dua bulan gak melaut. Kalau di darat kek gini ya itulah kerjanya makan tidur. Mau gimana lagi kita sudah ada sangkutan sama bos jadi kalau mau kerja lain ya harus bayar dulu, kalau gak ada sangkutan ya enak bisa kerja, jadi kita ini ya gak berkutik. Kalau gak punya pinjaman ya bisa bangunan kebun, disini gak ada kerjaan apa-apa ya kalau gak melaut mau makan apa"(Wawancara AW, 17/02/2017)

\section{Status Kepemilikan Lahan}

Kondisi pemukiman kumuh ini sebagian besar terjadi akibat status kepemilikan lahan tempat mereka membangun rumah yang masih merupakan milik PT.Pelindo II. 
PT.Pelindo II mulai ada sejak tahun 1984, sementara masyarakat pertama yang mulai menggarap lahan untuk mendirikan pemukiman sudah ada sejak tahun 1977. Namun pihak Pelindo II mengklaim bahwa tanah yang berada di Kelurahan Sumber Jaya adalah miliknya. Tanah ini masih dalam status sengketa yang suatu saat rumah mereka bisa saja digusur.

Tanah sengketa tanah ini tepatnya di RW 02 di mana 35,5 ha tanah dihuni oleh masyarakat yang mayoritas bekerja sebagai nelayan. Masyarakat nelayan di kawasan kampung nelayan RW 02 mengklaim bahwa pihak PT.Pelindo II belum memberikan ganti rugi terhadap lahan mereka seluas 35,5 ha. Dikatakan oleh pak Imam salah satu tokoh masyarakat yang sudah lama tinggal di Kelurahan Sumber Jaya sebagai berikut:

"Dulu itu dek, pihak Pelindo memang membeli lahan dari Jembatan Loncor Sungai Jenggalu sampai Teluk Belanak Kampung Bahari itu. Luasnya 135,5 hektar. Dulu satu hektar di bayar 50 ribu. Tapi 35,5 hektar lagi belum diganti rugi, alasannya karena mereka kehabisan dana. Jadi kami ini termasuk tinggal di lahan 35,5 hektar dek. Kami juga gak punya sertifikat lahan, sampe sekarang saya tidak bayar pajak, karena mau gimana lagi sertifikat nya saja tidak ada." (Wawancara Imam, 24/01/2017)

Keadaan ini membuat masyarakat yang memang sudah cukup mampu untuk membangun rumah memilih membangun rumah dengan semipermanen. Alasannya adalah agar suatu saat jika mereka digusur maka bangunan kayu dan papan sisa rumah masih dapat digunakan lagi, dan jika digusur mereka tidak akan terlalu rugi karena bangunan yang memang masih semipermanen.

Tidak adanya sertifikat sah yang menyatakan bahwa tanah yang ditempati adalah milik mereka, menjadi salah satu faktor pembentuk kemiskinan. Jika mereka mempunyai hak atas lahan yang mereka miliki sekarang, maka masyarakat bisa menggunakannya untuk mendapatkan modal dari pihak perbankan kemudian membuka usaha dengan memberi jaminan sertifikat lahan. Namun karena lahan yang dimiliki saat ini statusnya masih dalam sengketa, mereka hanya mempunyai hak mengggunakan lahan untuk membangun tempat tinggal.

Saat ini status lahan sengketa antara masyarakat Kelurahan Sumber Jaya dengan PT. Pelindo II sudah dialihkan kepemilikannya oleh pemerintah. Pemerintah berjanji akan memberikan sertifikat lahan kepada masyarakat, namun sampai saat ini janji tersebut belum dipenuhi PT Pelindo II merupakan Badan Usaha Milik negara (BUMN), sehingga saat ini sedang menunggu keputusan pemberian ijin dari pihak BUMN. 
Masyarakat berharap pemerintah dapat segera memenuhi janjinya memberikan sertifikat lahan kepada mereka.

Aset lahan untuk usaha seperti lahan pertanian juga tidak dimiliki oleh nelayan buruh. Nelayan buruh yang umumnya merupakan masyarakat pendatang tidak memiliki lahan untuk usaha pertanian. Jika mereka mempunyai lahan untuk usaha pertanian, maka itu dapat dijadikan alternatif mencari nafkah bila musim paceklik tiba.

\section{KESIMPULAN}

1. Karakteristik kemiskinan yang terjadi di Kelurahan Sumber Jaya dapat dilihat dari kondisi permukiman yang kumuh dan nelayan buruh yang sebagian besar hidup menyewa rumah kontrakan yang semi permanen. Akses nelayan terhadap kesehatan, di mana jika sakit mereka hanya membeli obat di warung dan belum semua nelayan buruh mempunyai kartu BPJS. Pendidikan nelayan yang rata-rata hanya sampai SMP dan anak nelayan yang masih jarang melanjutkan pendidikan sampai tingkat perguruan tinggi. Rumah tangga nelayan tidak memiliki aset produktif seperti sawah, kebun atau ternak yang dapat membantu memenuhi kebutuhan hidup sehari-hari.

2. Kemiskinan struktural pada umumnya ditandai oleh ketimpangan akses dan kontrol terhadap sumberdaya ekonomi, sosial, dan politik. Adapun dimensi struktural yang membentuk kemiskinan nelayan buruh adalah pola hubungan produksi (sistem bagi hasil tidak menguntungkan nelayan), pola hubungan sosial (hubungan patron klien menyebabkan ketergantungan yang tinggi antara nelayan kepada juragan), kebijakan pemerintah (implementasi kartu nelayan dan rumah nelayan tidak tepat sasaran), dan faktor lain (lemahnya akses permodalan dan konflik lahan).

\section{DAFTAR PUSTAKA}

[BPS] Badan Pusat Statistik.2010. Berita Resmi Badan Pusat Statistik.

Damayanti, E., S. Widiono, S. P. Utama. 2018. Mode of Production In Fishermen Community: Case Study of Relationship Between the Ship Owner and Labour of Fishermen in Pulau Baai Area, Bengkulu City. Agritropica: Journal of Agricultural Science. 1 (2): 99-110.

Hasibuan, F., S. Widiono, R. Badrudin. 2017. Resiliensi Struktur Keluarga Nelayan: Studi Kasus Respon Keluarga Nelayan Terhadap Dampak Perubahan Iklim Di Pantai Pasar Bawah Bengkulu Selatan. AGRISEP 16(2): 201-210. 
Kemiskinan Struktural Komunitas Nelayan Di Kelurahan Sumber Jaya.......

Kasim, M. 2006. Karakteristik Kemiskinan dan Strategi Penanggulangannya Studi Kasus : Padang Pariaman.Indomedia Global Jakarta. Jakarta

Kusnadi. 2000. Nelayan: Strategi Adaptasi dan Jaringan Sosial. Bandung: Humaniora Utama Press.

Mardimin, J. (Ed). 1996. Dimensi Kritis Proses Pembangunan di Indonesia. Yogyakarta: Kanisius.

Miles, M dan M. Huberman. 1992. Analisis Data Kualitatif. (Terjemahan). Jakarta, UI Press.

Pramudyasmono, Hajar G. Paulus Suluk Kananlua, dan Hasan Pribadi. 2011. Perilaku Masyarakat Miskin di Kota Bengkulu dan Model Pengentasan Kemiskinan Berbasis Nilai Sosial-Budaya Lokal. Jurnal Masyarakat, Kebudayaan, dan Politik 24(2): 151-161.

Satria, Arif. 2001. Dinamika Modernisasi Perikanan: Formasi Sosial dan Mobilitas Nelayan. Bandung: Humaniora Utama Press.

Setiadi, 2006. Mengungkap pengentasan Kemiskinan Secara Partisipatoris. https://ugm.ac.id/id/newsPdf/1741-

mengungkap.pengentasan.kemiskinan.secara.parsipatoris. [Diakses pada tanggal 15 Oktober 2016]

Soedjatmoko. 1984. Dimensi Manusia Dalam Pembangunan. Jakarta: LP3ES.

Soemardjan, Selo (Ed). 1984. Kemiskinan Struktural. Jakarta: YISS.

Sinaga, H. S. Widiono, Irnad. 2015. Pola Hubungan Patron-Klien pada Komunitas Nelayan di Kelurahan Malabro Kecamatan Teluk Segara Kota Bengkulu. AGRISEP 15(2): 167-176.

Stzompka, P. 2004. Sosiologi Perubahan Sosial. Jakarta: Prenada Media.

Sudarso. 2007. Tekanan Kemiskinan Struktural Komunitas Nelayan Tradisional di Perkotaan. Jurnal Masyarakat, Kebudayaan, dan Politik 20(2): 87-102.

Suyanto, Bagong. 2003. Upaya Menyejahterakan Nelayan di Jatim Meningkatkan Produktivitas atau Diversifikasi? http://www.kompas.co.id/kompascetak/ 0304/23/jatim/274420.htm. [Di akses pada tanggal 26 Oktober 2016]

Widiastuti, Tuti. 2010. Kemiskinan Struktural Informasi. Jurnal Ilmu Komunikasi 8(3): 314-329.

Wijayanti, N. 2008. Pola Hubungan Kerja Antara Nelayan Pemilik Kapal Purse Seine Dengan Buruh Di Pangkalan Pendaratan Ikan (PPI) Unit 2 Pantai Utara Desa Bajomulyo Kecamatan Juwana Kabupaten Pati (Studi Deskriptif Kualitatif Mengenai Pola Hubungan Kerja Antara Nelayan Pemilik Kapal Purse Seine Dengan Buruh Di Pangkalan Pendaratan Ikan (PPI) Unit 2 Pantai Utara Desa Bajomulyo Kecamatan Juwana Kabupaten Pati. Thesis (Unpublished). Surakarta: Universitas Sebelas Maret.

Yin, Robert K. 2014. Case Study Research Design and Methods (5th ed.). Thousand Oaks, CA: Sage. 